\title{
DA MÚSICA COMO SUBSTRATO POÉTICO EM JORGE DE SENA
}

\author{
Sebastião Edson Macedo"
}

\begin{abstract}
RESUMO: A decisão de Jorge de Sena em se tornar poeta está relacionada à audição musical de La Cathédrale engloutie, de Claude Debussy. Esta música desencadeou nele uma experiência estética transformadora que afetou diretamente seu olhar sobre a condição do homem no mundo. Os poemas do livro Arte de Música (1968) confirmam esta transformação a partir da meditação sobre diferentes peças musicais do repertório erudito ocidental, tanto no que tange à singularidade da escritura poética quanto à transfiguração do próprio estatuto subjetivo da lírica. Este artigo reflete alguns aspectos da relação dialética entre poesia e música que explicitam tais transformações e as colocam na base do processos de composição poética que Jorge de Sena chamou de «metamorfoses musicais».
\end{abstract}

PALAVRAS-CHAVE: Jorge de Sena; música e poesia; metamorfoses.

ABSTRACT: Jorge de Sena's decision to become a poet is related to his listening to La Cathédrale engloutie, by Claude Debussy. This piece of music motivated a transformational aesthetic experience in him, which influenced his perception of the human condition in the world. The poems of Arte de Música (1968) confirm this change when they focus on the different pieces of music from the erudite occidental repertoire, concerning both the singularity of the poetic writing and the transformation of the subjective status of the lyric. This paper presents some aspects of the dialectical relation between music and poetry in which such shift is in evidence, forming the basis for the poetic composition processes Jorge de Sena named «musical metamorphosis».

KEYWORDS: Jorge de Sena; music \& poetry; metamorphosis.

Não é preciso tirar a capa marrom: é uma harpa, de certeza, ao lado do piano modesto e silencioso. E, bem próximos, o violoncelo, a flauta doce, uma estável torre de diversas partituras empilhadas sobre uma das caixas acústicas do aparelho de som. A um canto da luz, ainda, uma poltrona confortável, que no recuo da composição coroa o ambiente. Não é necessário indagar à viúva: é a sala de música da Família Sena, na Califórnia, abarrotada - como, de resto, toda a casa - de livros que vão da historiografia medieval ao século XXI, do rodapé até o teto. E basta a despretensiosa audibilidade do aparelho de som, sintonizado na KCSB-FM, a Rádio Universitária de Santa Bárbara, a alternar breves notícias locais com música clássica variada, para que me veja recuar ao momento em que tudo começa para Jorge de Sena.

" Professor substituto e mestrando em Literatura Portuguesa na UFRJ, bolsista FAPERJ, (Programa «Aluno Nota 10»), prepara dissertação sobre a poesia de Jorge de Sena. Bolsista da Cátedra Jorge de Sena em 2003/2004. Membro do Pólo de Pesquisa sobre Relações Luso-Brasileiras (PPRLP), do Real Gabinete Português de Leitura. Este texto resulta de bolsa concedida pela Fundação Calouste Gulbenkian, em 2006, para pesquisa no espólio de Jorge de Sena, nos USA. 
Não me refiro, obviamente, a seu nascimento civil, em 1919, mas à gênese do poeta Jorge de Sena, cuja obra é, toda ela, gerada pela necessidade de uma voz dar conta do sentido abismal e súbito que a música disparou em seu espírito, em 1936. Refiro-me às «metamorfoses musicais» de Sena, cujos desafios trouxeram-me, quase 30 anos depois da morte do poeta, a esta casa: a casa do exílio definitivo. E esta sala, e este rádio ligado ao ritmo da rotina doméstica, é o que atualiza para mim o testemunho de uma incontornável experiência artística da história cultural e da literatura portuguesa no século XX.

Recuo para 1936, Lisboa. Um rádio Pilot recebe a transmissão radiofônica, provavelmente de Walter Gieseking, interpretando o prelúdio para piano n. ${ }^{\circ} 10$ de Claude Debussy, intitulado La Cathédrale engloutie. A casa agora é portuguesa, mas isso pouco altera a cena. Só os acordes perpassam cristalinos sob um fundo / que docemente ecoa. Música literata e fascinante (61-2) ${ }^{1}$, que começa a fraturar a subjetividade de um jovem português, instigando-o a uma introvisão radical, e nele gerando um homem constrangido pela necessidade da poesia, esta desgraça impotente de actuar no mundo, / e que só sabe negar-se e constranger-me a ser / o que luta no vácuo de si mesmo e dos outros (4-6). Ninguém desconfia de nada. Jorge de Sena teria então 17 anos.

E talvez isso seja tudo. Não há maiores notícias do que aí aconteceu senão o poema intitulado precisamente "La Cathédrale Engloutie, de Debussy» (mais a nota referente a ele), escrito no Brasil a 31 de Dezembro de 1964, meses antes de Jorge de Sena seguir de mudança para os Estados Unidos.

Deslocado do sequenciamento cronológico do livro Arte de Música para o «lugar» de uma ouverture das metamorfoses musicais, o poema é de fundo notadamente memorialístico, evocando, a partir daquela música de Debussy, esse dia que quase poderia ser chamado triunfal, à maneira de Fernando Pessoa. Não fosse o fato de que, no teatro heteronímico de Pessoa, há pronta e literalmente a idéia de um êxtase ${ }^{2}$ que a escrita de O Guardador de Rebanhos parece operar na encenação epistolar do «drama em gente», inscrevendo o nome de Alberto Caeiro como "mestre»; enquanto que, nesse testemunho poético-biográfico de Sena, a experiência do êxtase genesíaco se consubstancia na descoberta de uma visceral tragicidade inerente às fissuras da vida (41), que o sujeito seniano passa a perceber em si e no mundo. E, de fato, se o júbilo de um monumental alvorecer (71) do que em mim se fez poesia (63) sugere, acionado por aquele prelúdio, uma espécie de «dia triunfal» para o novo poeta, é preciso acrescentar que, em seu poema, outrossim, não faltam sugestões de algo como «o dia trágico», a partir do qual ficaram irremediavelmente expostas as fendas ténues que na vida / na minha e na dos outros, ou haviam ou faltavam (17-8).

Considerando que os paratextos senianos, para além do sentido autocrítico intrínseco, constituem um dispositivo de redobro do testemunho poético, invoco a nota que Jorge de Sena escreve a esse «poema de abertura», na qual afirma o im- 
pacto da peça de Debussy em sua vida, admitindo mesmo que foi sob a impressão dela que primeiro escrevi versos (SENA, 1977: 235). A nota vem sublinhar a consciência histórica da audição de La Cathédrale engloutie como fundadora do impulso poético seniano, sensível não só aos horizontes alargados de uma mundividência que se descortina, mas sensível sobretudo à visão profunda (53) da condição humana, capital em sua obra.

Sim, isto é tudo, porque todo o legado da experiência poética de Sena nasce exatamente daí, desse êxtase contrário a si mesmo, que contraria a identidade que o moço Jorge reconhecia em si: nunca mais pude ser eu mesmo (48); Passei a ser a sombra teimosa do que não existe (51). Esse «marco zero» da gênese do poeta foi propiciado justamente por se encontrar o sujeito num estado de latência face à linguagem poética - eu nada sabia de poesia, de literatura (2) -, de modo que a exposição à alta densidade estética da obra de Debussy permitiu uma descarga das representações simbólicas da linguagem musical sobre um rapaz / que era pretendido igual a todos eles: alto ou baixo funcionário público (6-7), desarticulando, nessa medida, sua tentativa de, dentro do território da fala cotidiana, dizer tudo isso (25) que ele absorvia através da música.

É, então, por via da desarticulação da linguagem usual, em paralelo ao desmonte da identidade pragmática do sujeito, que se poderá atingir o hipocentro dessa experiência estética, no qual o prelúdio já não é mais, ou somente, aquela música de Debussy, com suas sugestões, a juntar catedral, mar, luz etc., mas o foco de convergência, e mesmo origem, de todos os símiles imagéticos possíveis para aquela composição. O prelúdio é então experienciado sem o aparato semântico do verbo, ou seja, essencialmente enquanto música. Sua potência, nesse nível da audição, é de tal ordem que é capaz de engendrar na linguagem um veemente impulso para dar conta, pelo menos enquanto pretensão, dessa pletora de símiles instigados pela pura estesia da música. É assim que, diante da impossibilidade de restituir ao verbo a exata experiência da música, resta à insuficiente linguagem humana deixar-se impregnar por essa arte assêmica, cujo desenvolvimento técnico ${ }^{3}$ acaba por fazer nascer no homem uma nova dimensão discursiva. Essa dimensão é a lírica ${ }^{4}$.

Em todo o livro Arte de Música, o discurso subjetivo é armado em uma tensa e espessa estrutura sintática. Assim, a compacta meditação exercida pela lírica seniana resulta dessa impregnação das representações de mundo advindas da organização artística dos sons. Entretanto, por mais densa e complexificada que essa meditação se torne, deparar-se-á permanentemente com os limites miméticos inerentes à natureza semântica do verbo, de forma que só a música que comprei e estudei ao piano mo ensinou / mas sem palavras (26-7), a dizer tudo aquilo que, em sua expressão sonora, não se reduz a qualquer significado.

Esse é o fulcro de Arte de Música, e através dele Sena recorrerá, ao longo do livro, não a um, mas a vários procedimentos miméticos de escritura a fim de minimizar as dificuldades da abordagem lírica da música. Esses procedimentos represen- 
tam as diferentes possibilidades de subjetivação ante os sons. Destaco aqui, com base no conjunto de poemas do livro, oito dos procedimentos mais recorrentes:

1) apontar o efeito da audição da obra musical na própria subjetividade: Creio que nunca perdoarei o que me fez esta música (1);

2) descrever imagens, incluindo impressões estéticas dos efeitos musicais: um canto de oboé / com percussões pontuando o mundo a que assistimos, / ao som dos arcos de metais ( Sinfonia Fantástica, de Berlioz»);

3) estabelecer nexos entre um texto literário outro e a música, como nos poemas «Ouvindo poemas de Heine como lieder de Schumann» e "Canções de Schubert sobre textos de Wilhelm Müller»;

4) refletir sobre o compositor da música, a partir da obra composta, mas utilizando também dados biográficos ou outras fontes que circundam a criação da peça, como a carta deixada por Mozart sobre sua própria morte, referida em «Réquiem, de Mozart»;

5) recuperar o Zeitgeist onde nasce a obra musical: Era belo, era bom, era perfeito o Mundo ( «A Criação, de Haydn»);

6) depreender a natureza da arte musical a partir da própria música: [...] a música não é silêncio mas silêncio que / anuncia ou prenuncia o som e o ritmo ("Bach: Variações Goldberg»);

7) depreender a natureza humana a partir da natureza da arte musical: Como é difícil ser-se humano! ("Ouvindo as canções de Dowland»);

8) elevar a música ao patamar de «arte superior», louvando-a como arte liberta do verbo: [...] e então este milagre / acontece de a música dizer o que / as palavras apenas indicavam ou escondiam. ("Canções de Schubert sobre textos de Wilhelm Müller»).

Deste elenco (parcial) dos procedimentos senianos, chamo inicialmente a atenção para o fato de que a descrição estrita de impressões musicais representa apenas $u m$ procedimento (ou uma etapa, se quisermos) da escritura: a impregnação, marcada por traços contemplativos, de passividade. A variedade e o encadeamento desses procedimentos evidencia uma mudança no estatuto do diálogo seniano com a música, em que os traços inerentes a sua impregnação se transformam em ação e atividade interpretativa. Assim, o poeta realiza uma tentativa de cerco ao objeto musical, chegando, por vias que não dispensam o caráter investigativo $^{5}$, a se deparar com questões que remetem - não é por acaso que Arte de Música está recheada de perguntas - à essência de toda música (6. ${ }^{\circ}$ procedimento).

A escritura dos poemas do livro aponta para esse sentido ontológico da música. É em busca dele que se dá a passagem, freqüentemente num mesmo poema, de um procedimento de escritura a outro, como do $6 .^{\circ}$ ao $7 .^{\circ}$, e deste ao $8 .^{\circ}$, quando, por deslizamento discursivo, a lírica toca questões relativas à metafísica sobre vida, amor, morte, necessidade da arte, etc., encenando toda uma problematização da condição humana a partir da música.

O deslizamento discursivo que permite a Sena transitar por diferentes modos de abordagem da música pode ser entendido como um processo de transfiguração do discurso no interior da lírica, ou, nas palavras de Eduardo Prado 
Coelho, como uma metamorfose do estatuto da subjectividade (COELHO, 1984: 160). Nesse sentido, a metamorfose musical acaba por executar uma metamorfose derivada, de segundo grau, que é uma metamorfose subjetiva. Nos versos finais do poema «Wanda Landowska tocando sonatas de Domenico Scarlatti» (SENA, 1977: 180-1), por exemplo, o poeta, de ouvinte daquela apoteose / de ressurreição (resultante da música de Scarlatti, dos gestos de Landowska e dos sons de um instrumento abandonado, o cravo), transforma-se no próprio sujeito ressurrecto que, impregnado pela música, submerge em vida / percutindo / a solidão / triunfal. $\mathrm{Na}$ verdade, o sujeito transfigurador está consciente de se tornar um outro quando metamorfoseia a música: Nem a música, nem nós, somos os mesmos já («Bach: Variações Goldberg», idem: 178).

É justo nessa sutil operação de metamorfose subjetiva que se dá uma ruptura com aquele impulso primeiro (e afinal utópico) de perfazer, por meio da lírica, todo o horizonte de representação simbólica da música, pois aconteceu tamanha suspensão da realidade a ponto / de real e virtual serem idênticos (ibidem), que a expressão musical passa a ser confundida com a própria vida, e como esta, fica inapreensível em sua totalidade.

Assim, identificando música e vida, o poeta, no «Andante con Variazioni, em Fá Menor, de Haydn», atesta que a possibilidade de apreensão total da música só se dá na ruptura com ela, uma vez que só variando em torno de perdê-la a toleramos toda (idem: 181). Essa ruptura corresponde ao afastamento do sujeito lírico de um intuito de representar a objetividade formal da música, e, no limite, a um afastamento da própria música (quando dela, por exemplo, o poeta se olvida para meditar sobre a condição humana).

Essa leitura que proponho vai de encontro a uma crítica de Arte de Música que privilegie o mapeamento dos recursos da musicologia, da forma musical e das técnicas de composição junto ao texto poético. Primeiro, porque não é possível reconhecer as referências técnicas das peças musicais como dados suficientes para dar conta da amplitude de suas representações em texto. Segundo, porque Sena não se atém a esse tipo de tarefa mimética, e quando faz referências a termos musicológicos, é apenas a título de sugestão de imagens, e nunca sob intento de qualquer reprodução estética da música. E terceiro, porque as grandes questões de Arte de Música apontam, como já mencionei, para os problemas de uma ontologia musical enquanto expressão da vida humana, de forma que a música é apenas um mote para a meditação seniana. Assim, o poeta abdica de qualquer isomorfia entre a linguagem musical e o verbo, atravessa o incessante jogo de incongruências dialéticas entre estes dois diferentes sistemas sígnicos, e depara-se com uma escritura cujo efeito estético é a densa meditação de um sujeito, ele mesmo, em metamorfose.

Entretanto, ressalte-se que a transfiguração subjetiva acontece a partir das repetidas vivências de uma obra ou de um compositor (SENA, 1977: 217). Ela incorpora o connaisseur musical que Jorge de Sena era, constelando à complexidade 
meditativa dos poemas diversas referências exteriores à expressão sonora ${ }^{6}$. Dessa forma, acrescenta-se mais uma razão para a lírica não poder considerar, na metamorfose musical, apenas a pura objetividade do som vivenciada na audição.

A metamorfose musical ultrapassa a música e vem incitar uma metamorfose do sujeito. A transfiguração poética de Arte de Música dá-se, pois, na escritura de um discurso lírico notoriamente espesso que complexificou a recepção da música ao transfigurar o agente subjetivo que ouve a música.

Assim, assumindo uma competência musicológica sem fazer dela seu estandarte, Sena colocou o lirismo de seus poemas no mesmo limiar de irredutibilidade representativa em que se encontra a música, porque não se restringiu à música. Assim, entendo porque esse livro se chama Arte de Música à maneira de uma Arte Poética ${ }^{7}$.

E assim, buscando pensar esse «lugar» (ou esse «modo») musical nos poemas de Sena, torno à casa de Santa Bárbara, na calmíssima Randolph Road. Aqui encontro uma extensa discoteca de música erudita ocidental, compreendendo obras de mais de 350 compositores; partituras para vários instrumentos; programas de concertos e óperas diversos assistidos pelo poeta, com eventuais anotações impressivas; catálogos de discos de importantes selos fonográficos mundiais, com marcações para encomenda; livros sobre filosofia e estética da música, alguns com rastros de leitura do próprio poeta; e muitos outros índices que confirmam a constante imersão musical do ambiente de trabalho de Sena. E assim entendo sua vivência da música se repetir e atravessar uma prática cotidiana de criação, e em tudo se irradiar, fazendo dele um homem dedicado à escuta meditativa, numa atenção integral à responsabilidade de se perceber gerado pela potência da música.

Ainda está por ser feito um estudo mais amplo que esquadrinhe textualmente a presença da música e suas transformações poéticas na articulação da escritura seniana como um todo, posto que esse todo é uma projeção poligrafada da pulsão poética de Sena. Como ele mesmo comprova na entrevista que concedeu a Frederick Williams pouco antes de sua morte, em 1978: sempre achei que a poesia é a minha principal criação, mesmo quando estou fazendo coisas inteiramente diferentes da poesia. Penso que o sentido poético está sempre por detrás de tudo o que escrevo (SENA, 1985). Não posso deixar de sublinhar que, por trás, ou no fundo desse sentido poético, certamente, estará ela, a música.

${ }^{1}$ Versos que iniciam a penúltima estrofe do poema «La Cathédrale Engloutie, de Debussy», que abre o livro Arte de Música. As citações de versos que doravante farei deste poema terão seus números indicados entre parênteses.

${ }^{2}$ Fernando Pessoa assim escreve na "carta sobre a génese dos heterónimos»: [...] escrevi trinta e tantos poemas a fio, numa espécie de êxtase cuja natureza não conseguirei definir. Foi o dia triunfal da minha vida, e nunca poderei ter outro assim. Abri com um título, 
O Guardador de Rebanhos. E o que se seguiu foi o aparecimento de alguém em mim, a quem dei, desde logo o nome de Alberto Caeiro» (PessoA, 1946: 263-4).

${ }^{3}$ A técnica aqui é referida como procedimento utilizado pela pulsão lírica, desde seu primeiro estalo até sua emancipação efetiva através dos poemas. Esse procedimento está vinculado ao processo de amadurecimento do sujeito poético seniano, claro. Nesse sentido, não deixa de ser significativo para uma noção de «técnica das metamorfoses» na poesia de Jorge de Sena a observação de que, na sua trajetória de criação literária, já se operava a mímese musical antes de Arte de Música, e esta continuou a ser operada depois, tendo nos poemas deste livro seu ponto de inflexão mimética mais pronunciado (como atestam os poemas "Cinco natais de guerra, seguidos de um Fragmento em louvor de J. S. Bach", escrito em 1944, in: Pedra Filosofal (1950); e «Indignação extemporânea ouvindo o improviso opus 142, n. . 2, de Schubert», escrito em 1970, in: Visão Perpétua (1982)).

${ }^{4}$ Será interessante refletir aqui o quanto esse «nascimento» da lírica seniana não só corresponde, em termos de processo, à origem do gênero lírico segundo as teses de Nietzsche em O Nascimento da Tragédia, mas corresponde inclusive ao despontar da noção de individualidade no homem grego arcaico (cf. SNELL, 2001: 55-80). Seja como for, é significativo o arraigamento da lírica a um escopo musical de remotas eras, cuja etimologia confirma seu acompanhamento executado à lira.

${ }^{5}$ Sena, no posfácio de Arte de Música, sublinha o quanto as meditações do livro admitem um caráter de «investigação da música» realizada por meio da dilatação do horizonte de conteúdos estéticos que elas envolvem, ao se referir metonimicamente às músicas mimetizadas por meio dos autores que foram «estudados» (SENA, 1977: 218).

${ }^{6}$ Como é o caso do uso freqüente de dados biográficos de compositores, textos de canções ou libretos, sugestões advindas dos títulos ou das circunstâncias das composições, bem como informações culturais ou históricas contextuais a determinadas obras, já mencionado.

${ }^{7}$ Óscar Lopes levanta uma importante discussão sobre a relação entre uma Arte de Música conseguida verbalmente enquanto ontologia da Arte Poética (Cf. LoPES, 1986: 27-45).

Coelho, E. P. «Jorge de Sena, a estrutura da poesia e a metamorfose do sujeito». In: Estudos sobre Jorge de Sena. Org. Eugénio Lisboa. Lisboa: IN-CM, 1984.

Lopes, Óscar. «Uma arte de música». In: Uma Arte de Música e Outros Ensaios. Póvoa de Varzim: Oficina Musical, 1986.

Nietzsche, F. O Nascimento da Tragédia. São Paulo: Cia. das Letras, 2000.

Pessoa, Fernando. Páginas de Doutrina Estética. Lisboa: Inquérito, 1946.

Sena, Jorge de. Poesia II. Lisboa: Moraes, 1977.

- «Tudo quanto é humano me interessa». Entrevista a Frederick Williams. Lisboa: Jornal de Letras, Maio, n. ${ }^{\circ} 145,1985$.

Snell, B. "O despontar da individualidade na lírica grega arcaica». In: A Cultura Grega e as Origens do Pensamento Europeu. São Paulo: Perspectiva, 2001. 
